\title{
Representation of Women in the Beach of Pramoedya Ananta Toer
}

\author{
Nurul Rahmadani ${ }^{1(*)}$, Ngusman Abdul Manaf ${ }^{1}$ \\ ${ }^{1}$ Universitas Negeri Padang, Indonesia \\ *Corresponding author. Email: Nurulrahmadani952@gmail.com
}

\begin{abstract}
Gender injustice is also often seen in the positioning of women in a short story. This study aims to explain the position of women and how women's profiles are described as objects in the short story. This research is a qualitative study using the critical discourse analysis method of Sara Mills's model with the perspective of feminism. The data source of beach girl short stories is Pramoedya Ananta. The result of this research is that women are positioned as objects. This is evident from every narration of events that occur in the story. Women's profiles as objects are depicted as low education, tradition-bound, and living from poor families.
\end{abstract}

\section{Keywords: Gender, position, short stories}

\section{INTRODUCTION}

Women's position is often raised as a symbol of subtlety, emotional, and something that moves slowly. In addition, women are also so close to the idioms of deterioration, oppression and even the concept that has been accepted by most of our society that they are "objects" not "subjects" for men (Hasanudin, 2015). Feminist etymologically according to Ratna (2004) comes from the word femme (women), meaning women (single) who struggle to fight for women's rights (plural), as a social class. Feminism in Indonesia has not beenSupposedly fully implemented., events violence does not occur, if there is already protection against women. However, in reality there are still gender differences between men and women. Women are always objects in stories and news and their presence is always displayed by others. Therefore, women should be given the opportunity to become subjects so that gender equality between men will be seen. Analysis of model discourse Sara Mills analyzes gender representation in a text.

Analysis conducted to describe the female and male figures in a text about the meaning of gender. As for the elements that become an analysis of Sara Mills's model in (Eriyanto, 2009) as follows: (a) the representation refers to how a person, group, or certain opinion ideas are displayed as they should. Representation is very important in two respects (1) whether a person, group, or idea is displayed as it should be, (2) how the representation is displayed in a story. (b) the position of subject-object Sara Mills emphasizes representation as the most important part of the analysis that can describe how one party, group, person, idea, or event is displayed in a certain way in a news discourse or text that influences meaning when received by the public (Eriyanto, 2009). (c) the position of writer-reader Sara Mills explains that an important and interesting thing to discuss in this section is how the position of the reader is displayed in the text (2009). Sara Mills is of the view that in a text, the position of the reader is very important and must be taken into account (d) gender according to Caplan (1987) gender is a difference in behavior between men and women that can be seen apart from biological structures, most are actually formed to start social processes and cultural. Gender social science is defined as a pattern of male and female relations based on social characteristics. Gender equality and justice becomes aissue very importantand a commitment of nations including in Indonesia.

Gender equality means that there are equal conditions for men and women to obtain opportunities and their rights as human beings, so that they can play a role and excel in political, economic, social, cultural, educational, defense and social security and legal activities. (e) feminism is the awareness of the low position of women in society, and the desire to improve or change the situation Saptari and Holzner (in Sunarto, 2006). This was also explained by Dzuhayati (in Sunarto, 2006) that feminism is an ideology that departs from an awareness of the oppression and exploitation of women in society, whether in the workplace or in the context of society in a macro setting, and conscious actions both by women or men to change the situation.

The purpose of the feminism movement is to try to create a harmonious society without exploitation and discrimination, democratic, and free from classification, caste, and gender bias (sex). (f) Masculinity according to Barker (2001), Connell (2000), and Beyon (2007) explains masculine is a form of male construction. Masculine is not formed from birth but, masculine is formed from culture. The masculinity of a man can be seen from the "fatherhood" as a ruler in the family, and a figure who is 
able to become a female leader and make decisions major. (g) marginalization according to Alcock (in Alfitri, 2016: 1) marginalization is a phenomenon in the acquisition of economic, social andaspects educational by a group of people. In there are three marginalization, classification. (1) the marginalized conscious and embittered by marginalization and want it aborted. (2) marginalization, the marginalized are not aware they have been marginalized and marginalization continue applicable. (3) parties marginalized realized they had been marginalized but still receive such marginalization as part of their lives. This can be seen from previous studies including Tri (2011), Yohana (2013), Tantri (2014), Hasanuddin (2015), Orwela (2017), Sugiarica, et al (2017), Rina (2017), Riqiiyatul, et al (2017), Dwi (2018), Nada (2018). Mendong (2011) conducted a study on "Representation of Women in Ads Pond's". The results of his research that the white and glowing skin in a advertisement Pond's were simulacrum or something that did not exist in actual reality. White and radiant which depicts a beautiful woman is the reality image of a hyperality of white and luminous, Rina Budiwati Tri (2011) conducted a study entitled "Representation of Gender Discourse in Expressions in Indonesian and English: Critical Discourse Analysis". The results of his research are based on the analysis of critical discourse, there are aspects / characteristics of action, historical, context, power, ideology and representation so that it is known: (a) men are considered as representatives of many affairs (especially matters of success and goodness); (b) men as active parties in marriage and sexuality; (c) women have more roles in the domestic sphere; (d) women are made a parable of negative things; and (e) unequal relations between women and men.

Furthermore, Yohana (2013) conducted a study entitled "Representation of Polygamy in the Film of Sharing a Husband". The result of the research was the film "Sharing a Husband" trying to portray polygamy from the perspective of women even though in practice women were the object ofpractice. polygamyPaspita Yazid Tantri (2014) conduct research on "Representation of Minangkabau Women in Women's Journal". The results of his research are the image of the Minangkabau woman depicted in the text of the article with the figure of a woman who is weak and always a victim of regional regulations that are biased in customs and religion. Hasanudin (2015) conducted a study on "representation of the feminist values of amba figures in the novel Amba Karya Laksmi Pamuntjak". That there are two things that can be seen from the results of this study 1) the values of feminism, 2) this amba novel can be seen from the values of gender representation found in this amba novel religious, disciplined, creative, and social care.Orwella (2017) conducted a study entitled "Representation of the Women's Political Movement in News Journalism".

The results of the research that it was found that there are schemes in the text, namely the micro level and the level of meaning of all these aspects can be known how print texts and online media build feminism into the minds of the public or readers. Ayu Sugiarica, et al (2017) conducted research on "Representation of Women in a
Collection of Short Stories" BH "by Emha Ainun Nadjib". Ari Rohmah Rina (2017) conducted research on "Women's Portraits of Crime News Rape in Sindonews.Com Online Media". that women are described as being blamed or people who have a bad image. Kamillah, Rizqiyatul, et al (2017) conducted a study on "Construction of Women's Image in Women's Heartline Talk Show Programs" on Trans TV Based on Sara Mills's Critical Discourse Analysis Study. The results of his research that the results of the analysis showed (1) the representation of women in the talk show program "Heartline Women" occupying speakers in two positions at once, namely as a subject and object. Viora Dwi (2018) conducted research on "Gender and Feminism in the Pekanbaru Metro Express (MX) Newspaper: Study of Critical Discourse Analysis of Sara Mill's Perspective". The results of his research that (1) women who are victims only as objects in the news, while the perpetrators and police are subjects who tell the chronology of events, (2) readers will position themselves as men because the news is written based on information obtained from perpetrators and police. Hindawiyah Nada (2018) conducted a study on " Representation of Muslim Women in the Film Ayat Ayat Cinta: Reception and Reinterpretation of PKS Muslimah Activities". The results of his research are the position of women in stories that illustrate Muslim women more dominantly influenced by various factors outside the film, such as family, environmental, and organizational factors.

Based on the research that has been done it can be concluded that a number of people have done research on the position of women both in literary and non literary works, but there are still problems that have not been thoroughly explained by previous research. Namely, the position of women and the profile of women in the short story of Pantai Pantai by Pramoedya Ananta Toer, which tells the life of a girl who felt a deep wound because of an arranged marriage and divorce in her household. This research is based on reading material which contains feminism that places women as victims (objects). It is seen that the existence of women is increasingly marginalized. Researchers found many short stories about feminism, one of the short stories is "Pantai Pantai" by Pramoedya Ananta Toer. Therefore, researchers want to know how the description of a girl's subject-object position, especially in feminism is described, then how the profile of women in the story is depicted. As for the difference in research that researchers will do with previous research, namely how the position of women as objects in the short story Girls Pantai Karya Pramoedya Ananta Toer and howprofile women'sas an object in the short story of Pantai Pantai Karya Premoedya Ananta Toer.

\section{METHOD}

This type of research is qualitative using descriptive methods. The data used in this study is an excerpt from the text of the short story, Pramoedya Ananta Toer, which contains sentences describing the event. The data source of this research is a speech that contains a case of feminism. Data collection techniques used were documentary 
techniques and note taking techniques. Data analysis techniques in this study are grouped into three stages in accordance with the objectives of the study. First, explain the findings of the text that presents the victim as an object. Second, explain the findings of the text that displays the victim and the victim's profile in the story.

\section{RESULTS AND DISCUSSION}

Based on the position of women (women as objects). The events that tell the story of this arranged marriage to the figure of the girl beach shows that the beach girl plays as an object. This can be seen in the quotation from events such as.

"Gadis kecil yang malang, yang harus meninggalkan kampung nelayan untuk tinggal di rumah Bendoro".

Based on the utterances above, it is clear that the events experienced by the girl are written from the author's perspective, thus placing the girl as an object (victim), as a result the girl is portrayed as the injured party in the story.

Tabel 1. Position of women (women as objects)

\begin{tabular}{|c|c|c|}
\hline No & Peristiwa & Kutipan \\
\hline 1 & Peristiwa 1 & $\begin{array}{l}\text { Gadis kecil yang malang, yang harus } \\
\text { meninggalkan kampung nelayan } \\
\text { untuk tinggal di rumah Bendoro. }\end{array}$ \\
\hline 2. & Peristiwa 2 & $\begin{array}{l}\text { Dia adalah gadis yang dipilih secara } \\
\text { suka-suka untuk menjadi istri seorang } \\
\text { Bendoro-Priyai. Hal yang tak pernah } \\
\text { terbayang oleh dia sebelumnya. }\end{array}$ \\
\hline 3. & Peristiwa 3 & $\begin{array}{l}\text { Selama tiga bulan pertama Gadis } \\
\text { Pantai tidak boleh pergi ke } \\
\text { luar. Selama waktu itu, ia belajar } \\
\text { sopan santun priyayi, mengaji, } \\
\text { membatik, dan aturan-aturan lain } \\
\text { yang ditetapkan dalam rumah } \\
\text { Bendoro itu. Pada mulanya ia masih } \\
\text { ditemani ayah dan ibunya, tetapi } \\
\text { kemudian mereka pulang ke kampung } \\
\text { untuk bekerja seperti biasanya. } \\
\text { Selama tiga bulan itu, Gadis Pantai } \\
\text { merasa seperti dalam kurungan. Ia } \\
\text { sangat rindu ibu dan kampung } \\
\text { halamannya. }\end{array}$ \\
\hline 4. & Peristiwa 4 & $\begin{array}{l}\text { Gadis diceraikan oleh Bendoro dan } \\
\text { diusir dari istana megah tersebut. }\end{array}$ \\
\hline 5. & Peristiwa 5 & $\begin{array}{l}\text { Gadis tak butuh perhiasan dan emas } \\
\text { yang diberikan Bendoro, dia hanya } \\
\text { butuh bayi yang merupakan anaknya, } \\
\text { dibawa olehnya. }\end{array}$ \\
\hline
\end{tabular}

"Dia adalah gadis yang dipilih secara suka-suka untuk menjadi istri seorang Bendoro-Priyai. Hal yang tak pernah terbayang oleh dia sebelumnya". Based on the quote above it is clear that the Beach Girl as an object because the beach girl is a victim of arranged marriages who choose to be the wife of a Bendoro-Priyai. This story tends to benefit Bendoro, especially men who are positioned as subjects (perpetrators). So the meaning of this quote is that the woman is positioned as a submissive person. His obedient portrayal of the woman appears in the phrase "she is a girl who is chosen to be a wife of a Bendoro" Furthermore, the quote that shows women as objects is.

Selama tiga bulan pertama Gadis Pantai tidak boleh pergi ke luar.

Selama waktu itu, ia belajar sopan santun priyayi, mengaji, membatik

dan aturan-aturan lain yang ditetapkan dalam

rumah Bendoro itu.

Pada mulanya ia masih ditemani ayah dan

ibunya, tetapi kemudian

mereka pulang ke kampung untuk bekerja seperti biasanya.

Selama tiga bulan itu, Gadis Pantai merasa seperti dalam kurungan.

Ia sangat rindu ibu dan kampung halamannya

Based on the above quotation, it appears that only the offender has the opportunity to enjoy life properly. While the beach girl as an object must adjust as desired Bendoro in the story. Like having to study, not allowed to leave the house so that the beach girl feels confined. This is in accordance with the analysis model of Sara Mills (in Eriyanto, 2009: 201) which says that only those who are objects are not only unable to present themselves in the text.

"Gadis diceraikan oleh Bendoro dan diusir dari istana megah tersebut"

Based on the quote from the event above, Pantai Beach is described as an object or victim of Bendoro, her husband. He was divorced because of having a daughter. If we think about what is behind Bendoro's heart to divorce his wife just because she is pregnant with a daughter. Maybe it has something to do with Bendoro's ideology who don't want girls. And of course the male portrayal of women in this story is marginalized. As if women who have mistakes.

"Gadis tak butuh perhiasan dan emas yang

diberikan Bendoro, dia hanya butuh bayi yang

merupakan anaknya, dibawa olehnya."

The quote in the speech event above is another example of women as objects. The Beach Girl as an object in the quote is. He was a victim of Bendoro when he was about to be divorced Bendoro was given jewelry and gold. But beach girls don't need that. Because he needs a baby who is his child, brought by him. So, the meaning is, Beach Girls are victims of Bendoro's selfishness because they cannot provide boys.

\section{Profile of Women as Objects}

In the table below we can see how women's profiles are described as objects. The profile of women can be seen in terms of economics, Here is education, and culture.an explanation. 


\begin{tabular}{ccl} 
No & \multicolumn{2}{c}{$\begin{array}{c}\text { Short Beach Girl Profile Table } \\
\text { Profil } \\
\text { Perempuan }\end{array}$} \\
\hline 1. & Ekonomi & $\begin{array}{l}\text { Gadis Pantai terlahir sebagai } \\
\text { rakyat bawahan. }\end{array}$ \\
\hline $2 . \quad$ Pendidikan & $\begin{array}{l}\text { Dia seringkali dihina oleh seorang } \\
\text { bujang baru yang bernama } \\
\text { Mardinah hanya karena latar } \\
\text { belakang dia seorang anak } \\
\text { kampung yang tak berpendidikan. }\end{array}$ \\
& & $\begin{array}{l}\text { Perjodohan yang tiada hendak ia } \\
\text { inginkan, namun dengan berat } \\
\text { hati dia menjalankan apa yang } \\
\text { menjadi kehendak kedua orang } \\
\text { tuanya. }\end{array}$ \\
\hline 3. & Adat istiadat \\
& &
\end{tabular}

Economic problems in the text of the beach girl short story are associated withfigures beach girl who place objects in the text. This is evident from the writer who tells that the life of a girl from childhood experienced difficulties in her life from childhood. Furthermore, the issue of education makes the beach girl also the subject (victim) in the story. And another factor is the customs that make the beach girl must follow what the will that took both her parents.

\section{CONCLUSIONS}

Based on the analysis of the Beach Girl short story by Pramoedya Ananta Toer it can be concluded that the position of women as objects is always Women positioned as the object being told.in the Beach Girl short stories are discussed as point of view. In addition, the position of women as objects depicted has a background profile low education, poor, and obedient to tradition. So that the position of the subject (narrator) tends to be dominated by men. Maybe if this is related to culture or tradition, ideology authorshipcould be Pramoediya Ananta Toer writing this short story at the time when the matchmaking was rife because of the difficult life andbackground low educational. While from the ideology of Pramoedya Ananta Toer, writing male characters as subjects because of the position of men as decision makers because he has everything. In the sense of not having flaws. Meanwhile, from the side of women who have the nature of feminism can only accept what is the decision of the subject to the object.So that whateverfeels is the subjectnot appropriate to the object, then the subject can make decisions about what he will do to the object.

\section{REFERENCES}

[1] Eriyanto. (2009). Discourse Analysis: Introduction to Media Text Analysis. Yogyakarta: PT LkiS Printing Cemerlang.

[2] Brown, Gillian and George Yule (1996). Discourse Analysis. Jakarta: PT Gramedia Pustaka Utama.

[3] Moeloeng, J Lexy. (2006). Qualitative Research Methodology. Bandung: PT Remaja Rosdakarya.
[4] Sobur, Alex. (2009). Media Text Analysis: A Guide to Discourse Analysis, Semiotic Analysis, and Framing Analysis. Bandung: Teen Rosdakarya.

[5] We are Rizqiyatul et al. (2017). The Construction of Women's Image in the Curhan Hati Wanita Talk Show Program on Trans TV is based on the study of Sara Mills's Critical Discourse Analysis. Journal of Language Education and Sstra Indonesia Vol 7 No: 2. Viora, Dwi. (2018). Gender and Feminism in Pekanbaru Metro Express Daily (MX) Newspaper: Study of Critical Discourse Analysis of Sara Mills's Perspective. Journal of Familiar Champion Vol 3 Number 1.

[6] Mondong, Tonny (2011). Women's Representation in Pond's Advertising. Journal of Innovation Vol 8, Number 1. Gorontalo State University.

[7] Ningsih, revelation (2018). Islamic Education Values in the Novel "Faded Charm of Cleopatra" (analysis of Sara Mills's Critical Discourse Model). Lingua Franca Journal Vol 6, No. 2. University of Muhammadiyah Makassar.

[8] Yohana, Nora. (2013). Polygamy Representation in the Film "Sharing a Husband". Journal of Communication Science Vol 2, Number 2. Riau University.

[9] Yan, Prantya Shella. (2017). Marginalization of Women in the Sexual Harassment News of the September 2013 and July 2015 Memorandum Daily: Analysis of Sara Mills's Critical Discourse. Journal Vol 01 number 01.

[10] Orwella, Citra. (2017). Representation of Women's Political Movements in News Journalism News Text Analysis of Old Koran News about PKI Gerwani and 2014 Elections. Journal of Research Dynamics, Vol 17, No 1.

[11] Rina, Budiwati Tri. (2011). Representation of Gender Discourse in Expressions in Indonesian and English: Critical Discourse Analysis. Kawistara Journal Vol 1, No 3.

[12] Ayu, Sugiarica. (2017). Women's Representation in Collection of Short Stories "BH" by Emha Ainun Nadjib. Journal of the Faculty of Social and Political Sciences, Udayana University.

[13]Fauzan, Umar. (2014). Critical Discourse Analysis From the Faiclough Model to Mills. Journal of Education Vol 6 No1.

[14] Hindawiyah, Nada. (2019). Representation of Muslim Women in the Film Ayat Ayat Cinta: Representation and Reinterpretation of PKS Muslimah Activists, Fatayat and Nasyiatul Aisyiyah in Jember Regency. Indonesia Journal of Islamic Communication, Vol 1, No 2. 
[15] Muhmudah, Dede. (2012). Representation of Women in the Text of Domestic Violence (Analysis of Sara Mills Feminist Discourse in the Text Text "Now Here It Is" in Pos Kota Daily). Journal of Communication and Media Vol 16. No 2. 